if they prove to be unsatisfactory; the material and labour may have to be carried out in the open air with material and labour of varying quality; the conditions of excavation and foundation cannot be entirely foreseen until the ground is opened up ; the execution of the works also may result in damage to property belonging to other persons. In addition, the completion of the work may extend over several years, and the employer may desire to use the completed parts of the work before the final completion of the whole.

IT was formerly the custom to prohibit assignment and to allow subletting only when the previous permission of the engineer had been obtained. Recently it has become fairly common to provide a form to be attached to and filled up with the tender, upon which the contractor declares the names of the firms to which he desires to sub-let portions of the works, and if these firms are approved before the contract is sealed the contractor may straightway sublet work to these firms. The retention in the hands of the engineer of supreme power as sole arbitrator has, considering the terms and circumstances of present-day contracts, become rather an anachronism. old forms change slowly and some of the reforms suggested are not quite satisfactory. In Mr. Rimmer's opinion, some phrases and clauses now accepted as standard practice are confusing and ambiguous. The basic conditions upon which standard conditions should be framed must first be decided by the parties concerned. If the persons have different views, they are sometimes determined on the basis of compromise. But if the conditions are to be clear and unambiguous, there is no room for compromise on the manner and phraseology on which these principles are to be stated.

\section{Changing the Face of London}

IN his Friday evening discourse at the Royal Institution delivered on February 3, Sir Charles Bressey dealt with the question of "Bigger London or Better London ?" He illustrated by lantern slides the growth of Greater London since the Great Fire and described the complex administration of the area, now that its population has reached $9 \frac{1}{2}$ millions, equivalent to the entire population of Norway and Sweden. In twelve years time the population within a thirty-mile radius of Charing Cross may reach a 'peak' figure of $10 \frac{3}{4}$ millions. Meanwhile growth continues with such alarming rapidity that the inadequacy of British road communications has necessitated the preparation of the Highway Development Survey published by the Minister of Transport last May. Its recommendations, looking thirty years ahead, include the construction of about 123 miles of new routes in the L.C.C. area, 368 miles outside the L.C.C. area (exclusive of motorways) and motorways to a total length of 307 miles. The total cost will lie between $£ 160,000,000$ and $£ 230,000,000$. Sir Charles stressed the urgent need for a new eastwest route across London (the east-west connexion), for the completion of the South Circular Road, the formation of a loopway around the City, and the extension of the Thames Embankment so as to form a continuous riverside promenade extending for eight miles from Putney Bridge to the Tower of London. The incessant congestion of London's main roads in time of peace was some inkling of what might happen if a hurried evacuation had to be undertaken. If the Government decides that the present time is not propitious for the undertaking of extensive works of road construction, nothing can justify the postponement of measures for safeguarding the course of new routes, which include tunnels adapted for use as part of London's air-raid defence schemes.

\section{Sir Arthur Evans: Gifts to the Ashmolean Museum}

Sir Arthur Evans has presented to the Ashmolean Museum, Oxford, of which he was keeper for a period of twenty-five years ending in 1908, his unique collection of Minoan sealstones and gems, gold rings and jewels, as an accession to the recently rearranged 'Minoan Room'. The collection, as is recalled by the Oxford correspondent of The Times of February 2, is "far-famed and unrivalled", embracing every period and class of the Minoan gem-cutter's artprisms, button-seals, cylinders and ring bezels in steatite, cornelian, ivory and other materials, engraved with pictographs, scenes of ritual, bullfighting and other sports. Among the rings is the famous great gold ring of Nestor, the group of gold beads known as the Treasure of Thisbe, all engraved with scenes of ritual, combat and ancient legend. Since Sir Arthur began his archæological explorations in Crete in the early nineties of the last century, both while he was keeper of the Museum and after, he has been liberal in contributing to its collections examples of the objects discovered by him in his excavations. With this latest gift, the Ashmolean collection of Minoan antiquities becomes the most important and the most complete outside Crete itself. Recent alterations of the Museum, in which the largest archæological gallery has been divided into three sections, have made it possible for Sir Arthur, with the assistance of Miss Mercy MoneyCoutts, to make a new installation of Cretan antiquities, in which the older collections have been supplemented by groups of casts, numerous photographs, diagrams and water-colour drawings, with figurines, smaller antiquities and pottery which he has transferred to the Museum from his private cabinets. His benefactions have not, however, been confined to the donation of antiquities from Crete. They include classical antiquities, large series of Greek, Roman and Anglo-Saxon coins, and other objects, as well as the great collections of stone and bronze implements, Anglo-Saxon jewellery and othor material which belonged to his father, the late Sir John Evans.

\section{Morbid Heredity in Isolated Communities}

AN interesting study of morbid heredity in man in an isolated community by Dr. J. W. McFeeters, for which the Sir Charles Hastings Clinical Prize for 1937 has been awarded (Brit. Med. J., Feb. 4, p. 218), is made the basis of a suggestion that in view of the facilities for tracing family pedigrees in small isolated communities and the inbreeding imposed upon such 